\title{
Catalyzing denitrification of Paracoccus versutus by immobilized 1,5-dichloroanthraquinone
}

\author{
Huijuan Liu • Jianbo Guo $\cdot$ Jiuhui Qu • \\ Jing Lian • William Jefferson • Jingliang Yang • \\ Haibo Li
}

Received: 22 August 2011/Accepted: 6 November 2011/Published online: 16 November 2011

(C) Springer Science+Business Media B.V. 2011

\begin{abstract}
The accelerating effect of non-dissolved redox mediator (1,5-dichloroanthraquinone) on the biological denitrification was investigated in this paper using 1,5-dichloroanthraquinone immobilized by calcium alginate (CA) and a heterotrophic denitrification bacterium of Paracoccus versutus (GU111570). The results suggested that the denitrification rate was enhanced 2.1 fold by $25 \mathrm{mmol}^{-1} 1,5$-dichloroanthraquinone of this study, and a positive correlation was found for the denitrification rate and 1,5-dichloroanthraquinone concentrations from 0 to $25 \mathrm{mmol}^{-1}$. According to the change characteristic of $\mathrm{NO}_{3}{ }^{-}$and $\mathrm{NO}_{2}{ }^{-}$during the denitrification process, the tentative accelerating mechanism of the denitrification by redox mediators was put forward, and redox mediator might play the role of reduced cofactors like NADH, N(A)DH and $\mathrm{SDH}$, or the similar ubiquinol/ubiquinone $\left(\mathrm{Q} / \mathrm{QH}_{2}\right)$ role during the denitrification process.
\end{abstract}

H. Liu · J. Guo $(\bowtie) \cdot$ J. Qu · W. Jefferson

State Key Laboratory of Environmental Aquatic Chemistry, Research Center for Eco-Environmental Sciences, Chinese Academy of Sciences, Beijing 100085, China

e-mail: jianbguo@yahoo.com.cn

J. Guo · J. Lian $\cdot$ J. Yang $\cdot$ H. Li

School of Environmental Science and Engineering, Hebei University of Science and Technology, Yuhua East Road 70\#, Shijiazhuang City 050018, People's Republic of China
Keywords Denitrification ·

1,5-dichloroanthraquinone $\cdot$ Redox mediator .

Mechanism

\section{Introduction}

With the fast development of modern industry and agriculture, inorganic nitrogen compounds have become common contaminates in surface water and groundwater in recent years. Ammonium, nitrate and nitrite, discharged into the environment, can cause serious problems such as the eutrophication of rivers and deterioration of water sources, as well as hazards to human health (Wang et al. 2009; Wan et al. 2009; Chen et al. 2009).

Biological denitrification is the most common technology employed for nitrogen removal in wastewater treatment. This technology is an anoxic process in which nitrate is reduced to nitrite and subsequently to nitrogen gas by facultative denitrifying bacteria. Denitrifying bacteria are generally heterotrophic and utilize simple organic compounds as electron donors to achieve denitrification. Carbon source and waste management costs are usually responsible for more than $50 \%$ of the total costs of wastewater treatment, which creates a bottle-neck problem in these wastewater treatment technologies (Fernández-Nava et al. 2010). More and more new biological technologies have been developed to overcome shortcomings of previous technology in recent years, for example, the 
sulfur-limestone autotrophic denitrification (SLAD) process (Feleke and Sakaibara 2002; Prosnansky et al. 2002) and the combined bioelectrochemical and sulfur autotrophic denitrification system (CBSAD) (Wan et al. 2009). However, the low removal rate and efficiency is still a key problem in this field. Therefore, it is very important to find a novel and economical biological nitrogen removal processes.

As we know, quinones can accelerate the anaerobic conversion of perchlorate, arsenate, nitrate, nitrite, nitrous oxide and azo dyes as electron donors (ArandaTamaura et al. 2007; Lovley et al. 1999; Guo et al. 2007, 2010a, b; Van der Zee and Cervantes 2009). Recently, the simultaneous conversion of sulphide and nitrate in a denitrifying culture was reported to be enhanced with different dissolved redox mediators (Aranda-Tamaura et al. 2007), but continuous dosing of the dissolved redox mediators implies continuous expenses and continuous discharge of this biologically recalcitrant compound. And the catalyzing effect of novel non-dissolved redox mediator catalyzing biological denitrification (RMBDN) was first explored simplify (Guo et al. 2010a, b), and the activity retained over $90 \%$ of their original value after four repeated experiment (Guo et al. 2007). However, the RMBDN technology has to be conducted in detail for the accelerating mechanism and effects.

The aim of this study was to explore the accelerating mechanism and the effect of 1,5-dichloroanthraquinone on the denitrification processes of Paracoccus versutus (strain GW1), which was a new isolated denitrification bacterium and has the high denitrification efficiency.

\section{Methods and materials}

Chemicals

All chemical reagents were analytical grade and were purchased from Xiandai Ltd. (Shijiazhuang, China). The chemical structure of 1,5-dichloroanthraquinone was shown in Fig. 1.

Isolation and characterization of the heterotrophic denitrification bacterium

The heterotrophic denitrification bacterium (GW1) was isolated from the denitrification reactor in "The

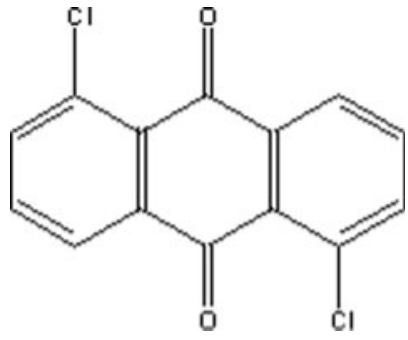

Fig. 1 The chemical structure of 1,5-dichloroanthraquinone

key laboratory of Environmental Biotechnology of Hebei', The sludge (5 ml) and buffer solution (45 ml) were mixed by the blender for $1 \mathrm{~min}$, and then deposited for $10 \mathrm{~min}$. About $10 \mathrm{ml}$ suspended liquid was added into the enrichment and isolation medium, which contained $100 \mathrm{ml}$ mineral medium with $1 \mathrm{ml}$ trace element solution. The mixed culture was cultivated in a shaker $\left(150 \mathrm{rev} \mathrm{min}^{-1}\right)$ at $30^{\circ} \mathrm{C}$. The plates containing bromothymol blue as indicator of the denitrification bacteria were incubated at $30^{\circ} \mathrm{C}$, and colonies were carefully observed for their uniformity and differences. The morphologically distinct colonies were selected and transferred to new plates to check for purity. Then the isolated bacterium was identified by the $16 \mathrm{~S}$ ribosomal genomic DNA according to previous paper (Guo et al. 2008). The optimum denitrification condition of the isolated bacterium was also conducted.

The enrichment and isolation medium contained the following $\left(1^{-1}\right): 0.1-0.3 \mathrm{~g} \mathrm{NO}_{3}{ }^{-}-\mathrm{N}, \quad 1.25 \mathrm{~g}$ $\mathrm{KHCO}_{3}, 0.025 \mathrm{~g} \mathrm{KH}_{2} \mathrm{PO}_{4}, 0.3 \mathrm{~g} \mathrm{CaCl}_{2} \cdot 2 \mathrm{H}_{2} \mathrm{O}, 0.2 \mathrm{~g}$ $\mathrm{MgSO}_{4} \cdot 7 \mathrm{H}_{2} \mathrm{O}, 0.00625 \mathrm{~g} \mathrm{FeSO}_{4}, 0.00625 \mathrm{~g}$ EDTA and $1 \mathrm{ml}$ trace elements solution. The trace element solution consisted of $\left(1^{-1}\right): 15 \mathrm{~g}$ EDTA, $0.43 \mathrm{~g}$ $\mathrm{ZnSO}_{4} \cdot 7 \mathrm{H}_{2} \mathrm{O}, 0.24 \mathrm{~g} \quad \mathrm{CoCl}_{2} \cdot 6 \mathrm{H}_{2} \mathrm{O}, 0.99 \mathrm{~g} \mathrm{MnCl}_{2}$ $.4 \mathrm{H}_{2} \mathrm{O}, 0.25 \mathrm{~g} \mathrm{CuSO}_{4} \cdot 5 \mathrm{H}_{2} \mathrm{O}, 0.22 \mathrm{~g} \mathrm{NaMoO}_{4} \cdot 2 \mathrm{H}_{2} \mathrm{O}$, $0.19 \mathrm{~g} \mathrm{NiCl}_{2} \cdot 6 \mathrm{H}_{2} \mathrm{O}, 0.21 \mathrm{~g} \mathrm{NaSeO}_{4} \cdot 10 \mathrm{H}_{2} \mathrm{O}, 0.014 \mathrm{~g}$ $\mathrm{H}_{3} \mathrm{BO}_{4}, 0.05 \mathrm{~g} \mathrm{NaWO}_{4} \cdot 2 \mathrm{H}_{2} \mathrm{O}$ per liter. $\mathrm{NO}_{3}{ }^{-}-\mathrm{N}$ was added into the influent synthetic wastewater in the form of $\mathrm{NaNO}_{3}$.

Biomass concentration was determined by optical density (OD) at $660 \mathrm{~nm}$, and the concentration of Strain GW1 was $5.8 \mathrm{mg}$ dry cell weight $\mathrm{l}^{-1}$ in all experiments.

\section{1,5-dichloroanthraquinone immobilization by Calcium alginate}

Calcium alginate was selected as the anthraquinone immobilization support according to the previous 
paper (Guo et al. 2007). The mixed immobilization solution with different 1,5-dichloroanthraquinone concentration $\left(\mathrm{g}^{-1}\right)$ and sodium alginate $\left(0.05 \mathrm{~g} \mathrm{l}^{-1}\right)$ was introduced into a syringe, and was then pressured to drop into a $5 \mathrm{~g} \mathrm{CaCl}_{2} 1^{-1}$ solution to form beads of $3.0-4.0 \mathrm{~mm}$ in diameter. The beads were suspended in the $\mathrm{CaCl}_{2}$ solution for $4 \mathrm{~h}$ to enhance their mechanical stability at $4^{\circ} \mathrm{C}$. The 1,5 -dichloroanthraquinone concentration was calculated by the mass ratio of added anthraquinone and the volume of the mixed solution for immobilization. The 1,5-dichloroanthraquinone weight of every bead was calculated using the ratio of the added 1,5-dichloroanthraquinone mass and the numbers of the bead.

The effects of 1,5-dichloroanthraquinone on the denitrification process

To evaluate the effect of 1,5-dichloroanthraquinone on the denitrification process, 1,5-dichloroanthraquinone immobilization beads were placed in $350 \mathrm{ml}$ growth medium containing $600 \mathrm{mg} \mathrm{NO}_{3}{ }^{-}-\mathrm{N}^{-1}$. Denitrification with an identical amount of 1,5-dichloroanthraquinone-free immobilization beads was also performed as the control. The residual nitrate and nitrite concentration in the solution was detected as a function of time until equilibrium.

The $\mathrm{pH}$ value is an important parameter for the denitrification processes. And the $\mathrm{pH}$ change was measured during the denitrification process with redox mediator.

The control experiment with 1,5-dichloroanthraquinone-free immobilization beads were similar to the procedures of immobilized 1,5-dichloroanthraquinone beads.

Analytical methods

The samples were centrifuged for $15 \mathrm{~min}$ at $8,000 \times g$ to remove the insoluble particles from the supernatant.

Nitrite concentration was measured by using the colorimetric methods and nitrate concentration was determined through UV-spectrophotometry (Tianmei, UV2600, UV/VS spectrophotometer, China). The $\mathrm{pH}$ was determined with a digital pH Meter (Delta-320, China).

\section{Results and discussion}

The optimum denitrification conditions of Paracoccus versutus

Strain GW1 was identified to be a member of Paracoccus versutus by $16 \mathrm{~S}$ rDNA sequence (1,416 bp, GU111570) analysis and physic-biochemical tests, respectively. It was a Gram-positive, non-motile, facultative, roundshaped bacterium measuring $0.7-1.0 \mu \mathrm{m}$ in diameter. No flagellum was found in their electron microscopy. Colonies were smooth, glistening, circular, lowconvex and white. It was oxidase-positive and catalase-positive. Sucrose, lactose, maltose, cellulose, mannitol and glycerol were not used by strain GW1 to produce acid compounds, and fructose was hydrolyzed.

The optimum temperature range of denitrification was $35-40^{\circ} \mathrm{C}$. The appropriate $\mathrm{pH}$ range was $7.0-8.5$. At the same time, sodium acetate was selected as the carbon source in this study, and the optimum ratio of $\mathrm{C} / \mathrm{N}$ was 6.0 .

The effect of 1,5-dichloroanthraquinone on the denitrification process

The adsorption results of 1,5-dichloroanthraquinonefree bead served as the blank control for the experiment. The $200 \mathrm{CA}$ beads caused little change $(0.2 \%)$ nitrate in $36 \mathrm{~h}$ (data not shown). Therefore, the adsorption of CA beads for nitrate could be neglected in the experiment in this study. With a fixed initial nitrate concentration (300 $\mathrm{mg} \mathrm{l}^{-1}$ ) because of many industrial wastewater containing high nitrate concentration (Shen et al. 2009; Rodriguez et al. 2007) and the 200 CA beads with different 1,5-dichloroanthraquinone concentrations, Fig. 2 showed that the denitrification rates by strain GW1 increased with the addition of 1,5-dichloroanthraquinone. Figure 3 also suggested that the $\mathrm{pH}$ value increased with the decrease of nitrate concentration for all experiments, but the $\mathrm{pH}$ value with 1,5-dichloroanthraquinone was lower than that of the control. The catalyzing denitrification process by 1,5-dichloroanthraquinone followed a modified pseudo-zero order model, which was $k=d C_{\text {Nitrate }} / d t$. The reaction constant of $k(\mathrm{mg}$ $\mathrm{NO}_{3}{ }^{-}-\mathrm{N} \mathrm{g}^{-1} 1^{-1} \mathrm{~h}^{-1}$ ) were 18.90, 24.68, 33.86, 37.96 and 42.61 at the 1,5-dichloroanthraquinone of $0,0.5,5.0,10.0$ and $25.0 \mathrm{mmol} \mathrm{l}^{-1}$ by multiple 


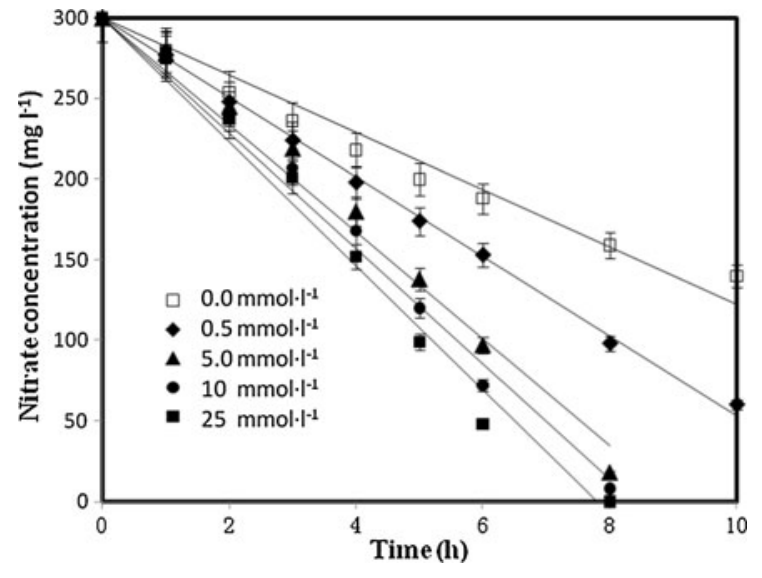

Fig. 2 The nitrate change curve of denitrification system with different concentration of 1,5-dichloroanthraquinone (Initial nitrate concentration: $300 \mathrm{mgNO}_{3}-\mathrm{N}^{-1} ; 35^{\circ} \mathrm{C} ; \mathrm{pH}$ : 7.0; carbon source: sodium acetate; $\mathrm{C} / \mathrm{N}: 6 ; 5.8 \mathrm{~g}$ dry cell weight $\mathrm{l}^{-1}$ )

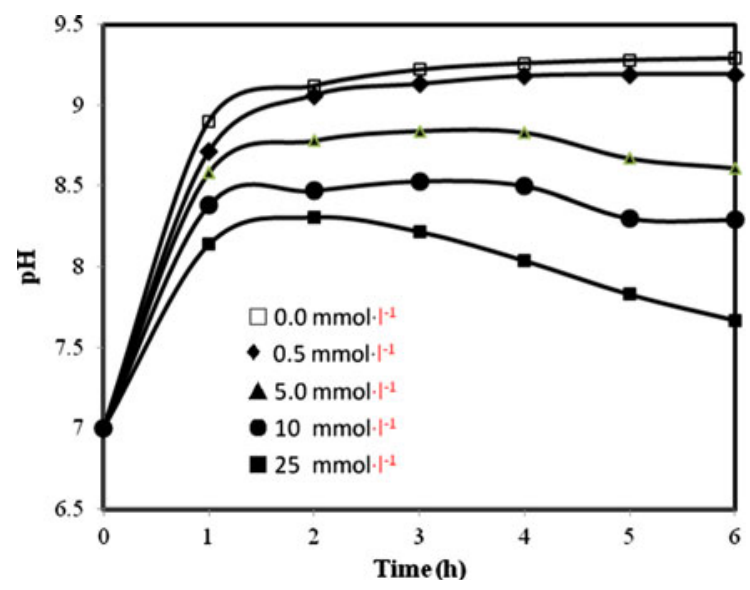

Fig. 3 The $\mathrm{pH}$ change curve of denitrification system with different concentration of 1,5-dichloroanthraquinone (Initial nitrate concentration: $300 \mathrm{mgNO}_{3}-\mathrm{N}^{-1} ; 35^{\circ} \mathrm{C} ; \mathrm{pH}$ : 7.0; carbon source: sodium acetate; $\mathrm{C} / \mathrm{N}: 6 ; 5.8 \mathrm{~g}$ dry cell weight $\mathrm{l}^{-1}$ )

regression analysis, respectively. A positive correlation was found for 1,5-dichloroanthraquinone concentrations from 0 to $25 \mathrm{mmol} \mathrm{l}^{-1}$ (Fig. 4), and the specific denitrification rate was enhanced 2.1 fold by $25 \mathrm{mmol} \mathrm{l}^{-1}$ 1,5-dichloroanthraquinone. When the 1,5-dichloroanthraquinone concentration was over $25 \mathrm{mmol} \mathrm{l}^{-1}$, the accelerating effect of 1,5-dichloroanthraquinone on the denitrification process was similar that of $25 \mathrm{mmol} \mathrm{l}^{-1} 1,5$-dichloroanthraquinone in this experiment, which might be related to the amount of nitrate reductase present. The accelerating effect by redox mediator on the denitrification was

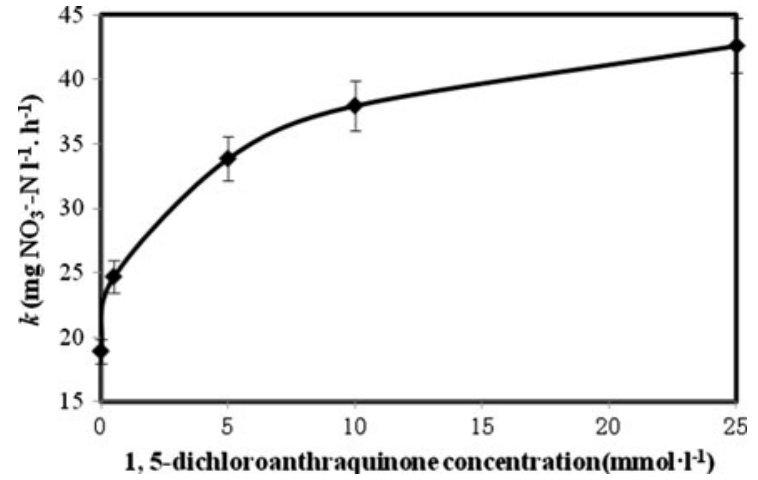

Fig. 4 Denitrification rate by strain GW1 with different concentration of 1,5-dichloroanthraquinone (Initial nitrate concentration: $300 \mathrm{mgNO}_{3}-\mathrm{N} \mathrm{l}^{-1} ; 35^{\circ} \mathrm{C}$; $\mathrm{pH}$ : 7.0; carbon source: sodium acetate; $\mathrm{C} / \mathrm{N}: 6 ; 5.8 \mathrm{~g}$ dry cell weight $1^{-1}$ )

similar to the results during the decolorization of azo dye (Guo et al. 2008). Different initial nitrate concentration (100-600 $\mathrm{mg} \mathrm{l}^{-1}$ ) was conducted to study the effect of nitrate concentration on the denitrification rate with $25 \mathrm{mmol} \mathrm{l}^{-1}$ 1,5-dichloroanthraquinone. Fig. 5 showed that the denitrification rate was not significantly affected by the initial concentration in the tested range of nitrate concentration and the average denitrification rate was $44.03 \pm 10.63 \mathrm{mg}$ $\mathrm{NO}_{3}{ }^{-}-\mathrm{N}^{-1} \mathrm{~h}^{-1}$ or $182.19 \pm 43.99 \mathrm{~g} \mathrm{NO}_{3}{ }^{-}-\mathrm{N} \mathrm{g}^{-1}$ dry cell weight $\mathrm{d}^{-1}$, which was enhanced 3-10 times compared to the reported data (Shen et al. 2009; Rodriguez et al. 2007).

During the denitrification process, the nitrite concentration was first accumulated up to the highest concentration and was then converted into nitrous

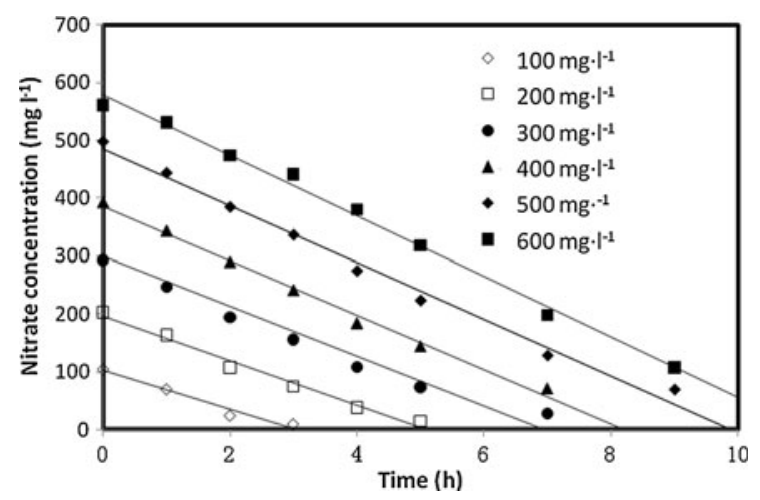

Fig. 5 The effect of different initial nitrate concentration on the denitrification efficiency with $25 \mathrm{mmol} \mathrm{l}^{-1} 1$,5-dichloroanthraquinone $\left(35^{\circ} \mathrm{C}\right.$; $\mathrm{pH}$ : 7.0; $25.0 \mathrm{mmol} 1^{-1} 1,5$-dichloroanthraquinone; carbon source: sodium acetate; $\mathrm{C} / \mathrm{N}: 6 ; 5.8 \mathrm{~g}$ dry cell weight $1^{-1}$ ) 
oxide, nitric oxide and nitrogen gas. The highest concentration of nitrite was about $132 \mathrm{mg} \mathrm{l}^{-1}$ with $25 \mathrm{mmol} \cdot 1^{-1}$ 1,5-dichloroanthraquinone at $6 \mathrm{~h}$ of reaction (Fig. 6). The reduction rate of nitrate to nitrite increased with the 1,5-dichloroanthraquinone concentration, and the reduction rate of nitrite was also enhanced by 1,5 -dichloroanthraquinone. Compared to the control ( $0 \mathrm{mmol} \mathrm{l}^{-1}$ 1,5-dichloroanthraquinone), the nitrate concentration was reduced completely and the removal rate was $80 \%$ after $8 \mathrm{~h}$ reaction. As we knew, the denitrification steps were sequential and the product of one enzyme is a preceding step for the next one. Fine-tuned regulation of the concentration and activity of the denitrification enzymes was, therefore, required in order to keep the free concentrations of $\mathrm{NO}_{2}{ }^{-}$and $\mathrm{NO}$ below cytotoxic levels. $\mathrm{NO}_{2}{ }^{-}$-reductase was induced in response to $\mathrm{NO}_{2}{ }^{-}$availability. The activity of $\mathrm{NO}_{2}{ }^{-}$-reductase gave rise to an initial increase of $\mathrm{NO}_{2}{ }^{-}$concentration.

The accelerating mechanism of redox mediator during the denitrification processes

The effect of redox mediator on the denitrification should be taken into consideration that two nitrate reductases are present in some strains: a periplasmic and a membrane-bound one (Alefounder and Ferguson. 1980; Bedzyk et al. 1999; van Spanning et al. 2006). In all bacteria, the enzymes of denitrification

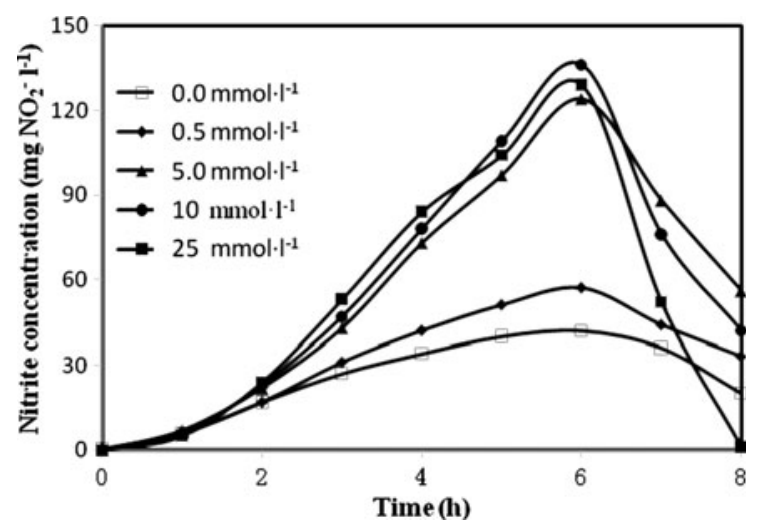

Fig. 6 The nitrite change during the denitrification processes with different concentration of 1,5-dichloroanthraquinone (Initial nitrate concentration: $300 \mathrm{mgNO}_{3}-\mathrm{N}^{-1} ; 35^{\circ} \mathrm{C} ; \mathrm{pH}$ : 7.0; carbon source: sodium acetate; $\mathrm{C} / \mathrm{N}: 6 ; 5.8 \mathrm{~g}$ dry cell weight $1^{-1}$ ) received $\mathrm{e}^{-}$from the respiratory chain system that was part of the cytoplasmic membrane. Denitrificationspecific components need to start at the ubiquinol/ ubiquinone component of the chains. Reduction of ubiquinone to ubiquinol occured using $\mathrm{e}^{-}$originating from reductants (such as NADH, succinate, etc.) during the denitrification process and ubiquinol can be directly oxidized by a membrane-bound respiratory $\mathrm{NO}_{3}{ }^{-}$-reductase (Fig. 7).

Figures 2 and 6 showed that redox mediator accelerated the denitrification of $\mathrm{NO}_{3}{ }^{-}$to $\mathrm{NO}_{2}{ }^{-}$and $\mathrm{NO}_{2}{ }^{-}$to $\mathrm{N}_{2}$, which needed the cofactor ubiquinol/ ubiquinone $\left(\mathrm{Q} / \mathrm{QH}_{2}\right)$. A co-metabolic reaction could be the main mechanism of the denitrification, in which the reducing equivalents or reduced cofactors like $\mathrm{N}(\mathrm{A}) \mathrm{DH}$ and succinate acting as secondary electron donors, channel electrons to $\mathrm{NO}_{3}{ }^{-}$and $\mathrm{NO}_{2}{ }^{-}$. There were three ways for the tentative accelerating mechanism of the denitrification by redox mediator (Fig. 7): (1) A represent that redox mediator severed as reduced cofactors like $\mathrm{N}(\mathrm{A}) \mathrm{DH}$ and succinate acting as a secondary electron donor, channel electrons to $\mathrm{NO}_{3}{ }^{-}$ and $\mathrm{NO}_{2}{ }^{-}$. The accelerating effect of redox mediator would be due to an electron shuttle between reduced enzyme cofactor $\left(\mathrm{Q} / \mathrm{QH}_{2}\right)$ and redox mediator; (2) B represent that redox mediator severed as the reducing equivalents shuttling electron between reduced enzyme cofactor $\left(\mathrm{Q} / \mathrm{QH}_{2}\right)$ and $\mathrm{NO}_{3}{ }^{-}$-reductase; (3) $\mathrm{C}$ represent that redox mediator served a similar role as the reduced enzyme cofactor $\left(\mathrm{Q} / \mathrm{QH}_{2}\right)$.

As discussed above, redox mediator might play the role of the reducing equivalents, reduced cofactors like $\mathrm{N}(\mathrm{A}) \mathrm{DH}$, and succinate, or the similar ubiquinol/ ubiquinone role during the denitrification process. Redox mediator might affect the cell behavior in different ways, i.e. reducing the redox potential and shifting the cytoplasmic ubiquinol/ubiquinone balance in favor of the reduced form. That was why an explanation for the accelerating effect on the denitrification could be sought in terms of an alteration of the enzyme properties and of cofactor regeneration. This also explained the similar role of NADH and redox mediator for the accelerating effect during the decolorization (Russ et al. 2000; Keck et al. 1997). In our research group, the catalyzing mechanism of redox mediator on the denitrification is also studying by using cell extracts and purified enzymes, which would allow a better understanding on the nature of the process. 


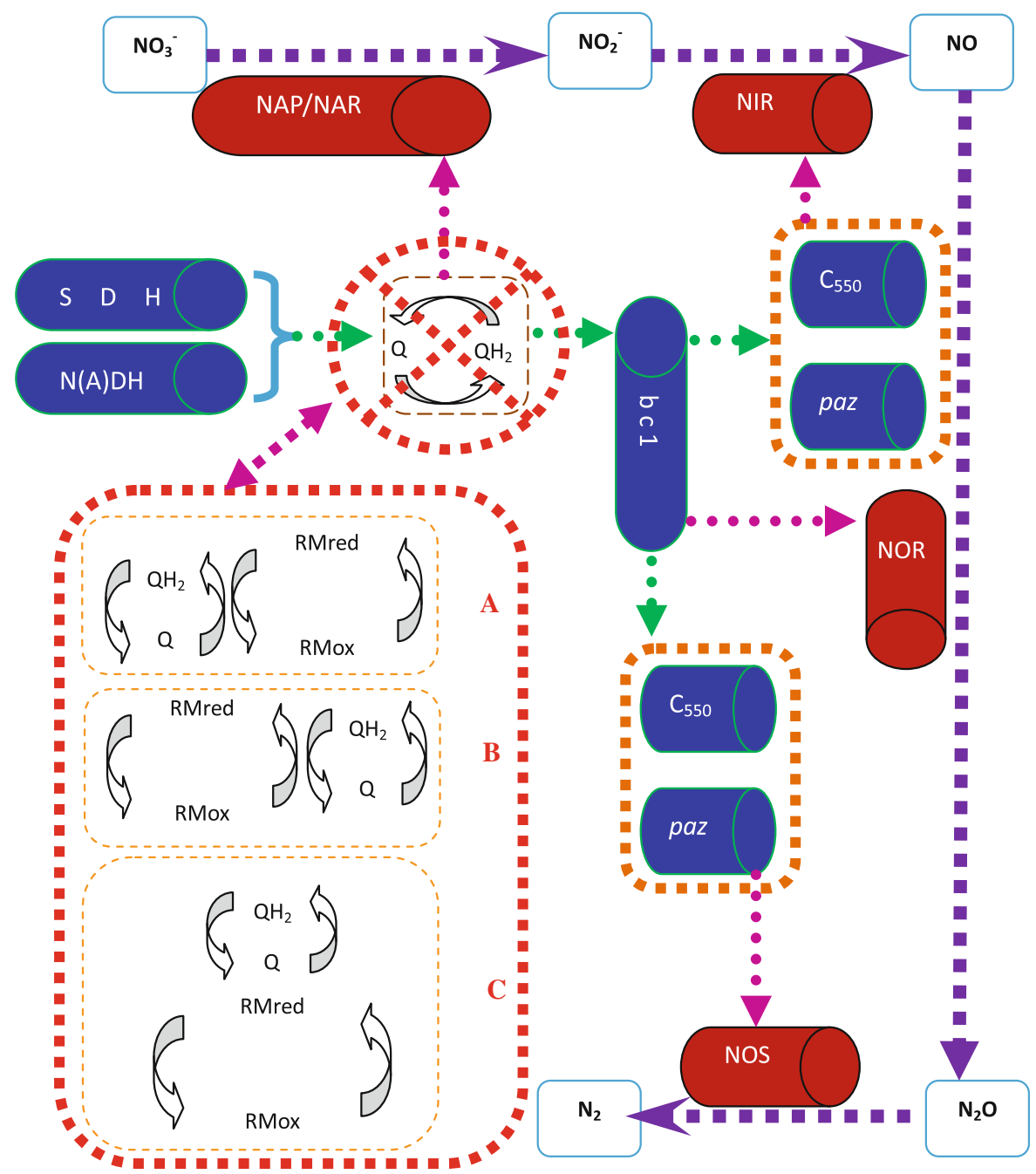

Fig. 7 The denitrification pathway with redox mediators and involved enzyme. $S D H$ succinate dehydrogenase, $N(A) D H$ dehydrogenase, $b c_{1}$ cytochrome $\mathrm{bc}_{1}$ complex, $c_{550}$ cytochrome c, paz pseudoazurin, NAR membrane-bound $\mathrm{NO}_{3}{ }^{-}$-reductase,

\section{Conclusion}

(1) It was observed that the artificial redox mediator 1,5-dichloroanthraquinone was capable of raising the denitrification rate 2.1 fold with $25 \mathrm{mmol} \mathrm{l}^{-1}$ concentration in this study, and a positive correlation was found for the denitrification rate and 1,5-dichloroanthraquinone concentrations from 0 to $25 \mathrm{mmol}^{-1}$.

(2) According to the change characteristic of $\mathrm{NO}_{3}{ }^{-}$ and $\mathrm{NO}_{2}{ }^{-}$during the denitrification process, the accelerating mechanism of redox mediator was first
NAP periplasmic $\mathrm{NO}_{3}{ }^{-}$-reductase, NIR cd ctype $\mathrm{NO}_{2}{ }^{-}$reductase, $N O R$ bc-type NO-reductase; $\mathrm{NOS}, \mathrm{N}_{2} \mathrm{O}$-reductase, $Q, Q H_{2}$ ubiquinol/ubiquinone, $R M$ redox mediator, red reduced, ox oxidized

presumed to act as a reducing equivalent, such as reduced cofactors like NADH, NAD(P)H and succinate, or the similar ubiquinol/ubiquinone role during the denitrification processes.

Acknowledgments This study was supported by the National Natural Science Foundation of China (Grant No. 50978082), China Postdoctoral Science Foundation (Grant No. 20100480485), the National High Technology Research and Development Program of China (Grant No. 2009AA06Z307) and the Program for New Century Excellent Talents in University (Grant No. NCET-10-0127). 


\section{References}

Alefounder PR, Ferguson SJ (1980) The location of dissimilatory nitrite reductase and the control of dissimilatory nitrate reductase by oxygen in Paracoccus denitrificans. Biochem J 192:231-240

Aranda-Tamaura C, Estrada-Alvarado MI, Texier AC, Cuervo F, Gomez J, Cervantes FJ (2007) Effects of different quinoid redox mediators on the removal of sulphide and nitrate via denitrification. Chemosphere 69:1722-1727

Bedzyk L, Wang T, Ye RW (1999) The periplasmic nitrate reductase in Pseudomonas sp. strain G-179 catalyzes the first step of denitrification. J Bacteriol 181:2802-2806

Chen H, Liu S, Yang F, Xue Y, Wang T (2009) The development of simultaneous partial nitrification, ANAMMOX and denitrification (SNAD) process in a single reactor for nitrogen removal. Bioresour Technol 100:1548-1554

Feleke Z, Sakaibara Y (2002) A bio-electrochemical reactor coupled with adsorber for the removal of nitrate and inhibitory pesticide. Water Res 36:3092-3102

Fernández-Nava Y, Marãnón E, Soons J, Castrillón L (2010) Denitrification of high nitrate concentration wastewater using alternative carbon sources. J Hazard Mater 173: 682-688

Guo J, Zhou J, Wang D, Tian C, Wang P, Salah Uddina M, Yu H (2007) Biocatalyst effects of immobilized anthraquinone on the anaerobic reduction of azo dyes by the salt-tolerant bacteria. Water Res 41(2):426-432

Guo J, Zhou J, Wang D, Tian C, Wang P, Salah Uddina M (2008) A novel moderately halophilic bacterium (GTW) for decolorizing azo dye under high salt condition. Biodegradation 19:93-98

Guo J, Kang L, Wang X, Yang J (2010a) Decolorization and degradation of azo dyes by redox mediator system with bacteria. In: Erkurt Atacag H (ed) Biodegradation of azo dyes, vol9. Springer, Dordrecht, pp 85-100

Guo J, Kang L, Yang J, Wang X, Lian J, Li H, Liu C, Li Z, Yue L (2010b) Study on a novel non-dissolved redox mediator catalyzing biological denitrification (RMBDN) technology. Bioresour Technol 101:4238-4241
Keck A, Klein J, Kudlich M, Stolz A, Knackmuss HJ, Mattes R (1997) Reduction of azo dyes by redox mediators originating in the naphthalenesulfonic acid degradation pathway of Sphingomonas sp. strain BN6. Appl Environ Microbiol 63:3684-3690

Lovley DR, Fraga JL, Coates JD, Blunt-Harris EL (1999) Humics as an electron donor for anaerobic respiration. Environ Microbiol 1:89-98

Prosnansky M, Sakakibara Y, Kuroda M (2002) High-rate denitrification and SS rejection by biofilm-electrode reactor (BER) combined with microfiltration. Water Res 36(36):4801-4810

Rodriguez L, Villasenor J, Fernández FJ (2007) Use of agrofood wastewater for the optimisation of the denitrification process. Water Sci Technol 55(10):63-70

Russ R, Rau J, Stolz A (2000) The function of cytoplasmic flavin reductases in the reduction of azo dyes by bacteria. Appl Environ Microbiol 66:1429-1434

Shen J, He R, Han W, Sun X, Li J, Wang L (2009) Biological denitrification of high-nitrate wastewater in a modified anoxic/oxic-membrane bioreactor (A/O-MBR). J Hazard Mater 172(2-3):600

Van der Zee FP, Cervantes FJ (2009) Impact and application of electron shuttles on the redox (bio)transformation of contaminants: a review. Biotechnol Adv 27:256-277

van Spanning RJM, Richardson DJ, Ferguson SJ (2006) Introduction to the biochemistry and molecular biology of denitrification. In: Bothe $\mathrm{H}$, Ferguson SJ, Newton WE (eds) Biology of the nitrogen cycle. Elsevier, Amsterdam, pp 21-36

Wan D, Liu H, Qu J, Lei P, Xiao S, Hou Y (2009) Using the combined bioelectrochemical and sulfur autotrophic denitrification system for groundwater denitrification. Bioresour Technol 100:142-148

Wang J, Lu H, Chen J, Ngai Lau JG, Tsang WL, van Loosdrecht MCM (2009) A novel sulfate reduction, autotrophic denitrification, nitrification integrated (SANI) process for saline wastewater treatment. Water Res 43(9):2363-2372 